Peter Palm

Lecturer Malmö University

Urban studies

Malmö University

20506 Malmö

Sweden

peter.palm@mah.se

+4640-665 7711

\title{
Measuring Customer Satisfaction: A Study of the Swedish Commercial Real Estate Industry
}

\begin{abstract}
Purpose - The aim is to identify the strategies of formal customer evaluations and the use of Satisfied Customer Index in the Swedish commercial real estate industry.

Design/methodology/approach - This research is based on an inventory of twenty-four commercial real estate companies use of formal customer evaluations and an analysis of fifteen interviews with top-level managers in the Swedish commercial real estate sector.

Findings - Only half of the companies included in the study conduct formal evaluations, although they are considered to work customer oriented. Two different strategies for using formal evaluations is, for improvement work and for signalling quality. One proposed explanation to why only half of the companies conduct formal evaluations is the possibility that the official Swedish Real Estate Barometer is not sufficient if the company would like to use the result for organisational development. There are instead indications that this Barometer mainly is used in publicity and marketing purpose, to signal quality.

Research limitations/implications - The research in this paper is limited to Swedish commercial real estate sector. But, the overall strategies for conducting formal evaluations should be applicable in general.

Practical implications - The insight the paper provides regarding how the industry perceive the Swedish Real Estate Barometer gives direct implications of improvements of the barometer.

Originality/value - It provides an insight regarding the use of formal customer evaluations and a proposition of how the Swedish Real Estate Barometer could be changed to better support and fulfils the aim of being a barometer for benchmarking.

Keywords - Commercial Real Estate, Customer Relations, Customer Evaluation, Quality in Real Estate Management,
\end{abstract}

Paper type Research paper

\section{Introduction}

Organisations approach customer satisfaction in various ways when managing and improving their relationships with customers (Sandblad, 2007 and Gilbert \& Veloutsou, 2006). In the past decade, work involving customer satisfaction has received a great deal of attention (Kärnä et al., 2009) as the real estate industry becomes more competitive and part of an increasingly dynamic environment (Lind \& Lundström, 2011 and Phillips \& Roper, 2009). Anderson and Sullivan (1993) emphasize that customer satisfaction is crucial for a company to be competitive and profitable (see also Sanderson, 2014). Initially, investing in customer relations to achieve customer satisfaction may be deemed (see Westlund et al., 2005) an 
unnecessary expense, but it will likely become cost-effective in time and have a positive impact on profitability. The driving force behind this investment appears to be the goal of a good reputation and more positive word-of-mouth from customers. Kristensen and Westlund (2004) conclude that these should be followed-up and measured to achieve better business results. In line with this, Gale (1994) concludes in his book Managing Customer Value that companies need a comprehensive strategic navigation system to provide data on both financial and customer value performance.

Kärnä et al. (2009) state that measuring customer satisfaction has several benefits for organisations: improved communication, recognition of demand, better understanding of problems, evaluation of progress as well as the monitoring and reporting of accomplished results and changes. Several researchers also advocate that it has a strong positive impact on both returns for the company (Westlund et al., 2005) and for shareholders (Aksoy et al., 2008). Tuli and Bharadwaj (2009) also claim that disclosing the customer satisfaction rate in an annual report has a positive impact on a stock's risk determination. Research points at the importance of monitoring, measuring, and evaluating customer relationships and satisfaction to gain a strategic advantage over competitors. These aspects are all well documented, but what about the actors? What is the underlying motive of the companies? This side of the commercial real estate industry is not as well researched.

This article aims to identify the strategies of formal customer evaluations and the use of the Satisfied Customer Index within the Swedish commercial real estate industry ${ }^{1}$.

Sweden has a tradition of measuring customer satisfaction; in fact, Sweden was the first country to establish a national indicator for customer satisfaction (Fornell, 1992). This tradition makes it even more interesting to research the Swedish commercial real estate industry and explore the strategies of companies regarding formal customer evaluations and the use of the Satisfied Customer Index (SCI). Furthermore, conducting formal customer evaluations and/or participating in the Swedish Real Estate Barometer (SREB) can be a way to work with and develop a service concept. It can also be a way to compare a company with other companies' results and also within the organisation. Previous studies show that the real estate industry has developed to become more service and customer oriented (Phillips and Roper, 2009 and Palm, 2013). This implies that measuring customer satisfaction should be of great interest for the industry. Addressing this question first constitutes an elaboration of what customer satisfaction is and the relation to real estate management, before we can outline the concept of measuring customer satisfaction.

\section{Customer satisfaction and orientation in real estate management}

This section is divided into two parts. The first part contains a general discussion regarding customer satisfaction, the definition of customer satisfaction, and an outline of the importance of working with customer satisfaction. The second part discusses customer satisfaction in the context of real estate management.

\subsection{Customer satisfaction}

Customer satisfaction has long been regarded as important within the management field (Lai et al., 2003). This attention is because high customer satisfaction has many benefits for the

\footnotetext{
${ }^{1}$ Commercial real estate industry is defined according to Lind and Lundström (2011) to be the part of the industry not focused on residential real estate.
} 
firm. Fornell (1992) concludes that high customer satisfaction enhances the firm's reputation, increases customer loyalty, and lowers the cost of future transactions.

Several researchers (see Grönroos, 2008 and Appel-Meulenbroek, 2008) have recently emphasized that a company's good reputation quickly translates into market shares and profits. In research involving twelve different sectors, Reichheld (1996) shows that the retention of five percent more customers increases profit up to forty percent in office building management. An effective customer relationship can do more than simply build on internal plans regarding customer relations. Payne and Clark (1995) state the following:

The adaptation of the relationship philosophy as a key strategy issue is more important than a written plan. For example, a formal marketing plan for internal markets is of little value if customer contact staff are not motivated and empowered to deliver the level of service quality required. (Payne and Clark, 1995, p. 322)

Current literature (see, for example, KärmäGee, Coates \& Nicholson, $200 \underline{8} 4$ or Grönroos, 2008) confirms that customer satisfaction is a function of perceived quality and disconfirmation; it is always the market's perception of the service compared to the eompetitors which determines quality (Gale, 1994).. At the same time, service quality is not a distinct factor nor an indistinct concept (Zineldin, 2006), but rather as defined by Grönroos (2008), what customers think is quality, and the quality of a service can only be as high as the customer perceives it. It is always the market's perception of the service compared to the competitors which determines quality and thereby difficult to examine as stated by Gallarza, Gil-Saura and Holbrook (2011). As service has been defined as a perception of the customer, we can now examine service in the context of real estate management.

\subsection{Customer satisfaction in the context of real estate management}

Unlike manufacturing and certain service industries, the real estate sector is not simply selling products and services; it involves a much more diverse service relationship with long-term contracts as well as "selling" their reputation in both contact with their customers and with their customer's buyer. This is important because the commercial real estate market is demand-driven, as Appel-Meulenbroek (2008) states. Li (2003) and Matzler and Hinterhuber (1998) conclude that the cost of attracting new customers is much higher than for keeping current customers. Focusing on current customers' needs can be rewarding; therefore, the real estate industry concentrates on retaining their customers instead of attracting new tenants. Pinder et al. (2003) also stress the importance of tenants and the rewards of treating them as valued customers.

As the real estate industry realizes the importance of customers, so too have the customers become more demanding concerning the services delivered. Baharum et al. (2009) claim that tenants today are more aware of the level of service they receive. Moreover, commercial buildings have become more complex with high-level technology requiring highly knowledgeable managers (Chin and Poh, 1999). This is a complex situation for the real estate manager who must meet the demands of high-level technology and satisfy customers expecting high-quality service. In fact, Lindholm (2008) believes level of service is the most essential task for a manager and that improving service and the service relationship should be amongst a property manager’s top priorities. 
Kärnä (2004) discusses the importance of delivering good service to render customer satisfaction and concludes that customer satisfaction leads to a stronger relationship between customer and company. Further, Jones and Sasser (1995) believe that customer satisfaction is the key to securing customer loyalty and long-term relationships. According to Storbacka et al. (1994), long-term relationships with customers are profitable for both customer and company (provider) and are essential in the real estate industry because of the long-term contracts and high transaction costs.

Appel-Meulenbroek (2008) believes that retaining tenants requires more efforts in maintaining a good relationship than competing through simply offering a good price/quality ratio. The valuation process of certain "keep" factors is mainly subjective from the tenants" side. Also, "push and pull” factors, which are mainly technical, can only raise satisfaction to a certain extent. On the other hand, the "keep" factors, which are mostly functional, are essential in retaining tenants given that satisfied tenants are more likely to feel a sense of commitment to the landlord and remain in the commercial space (Dogge and Smeets, 2004). Also Sandersson (2015) conclude that the aspects with most impact on tenants satisfaction with property management are communication and understanding of the tenants needs.

\section{Measuring customer satisfaction}

This section is divided into two parts. In the first part, a general description of measuring customer satisfaction is given, and the arguments, for performing this kind of formal evaluation, are also discussed. In the second part, the Swedish Real Estate Barometer (SREB) is described and outlined.

\subsection{Measuring customer satisfaction}

As concluded in previous sections, the importance of customer satisfaction is clearly well known both in general and also within real estate management. This recognition has prompted various companies to conduct customer satisfaction evaluations. Outside companies also supply specific indexes (barometers) which serve the real estate industry. This relates to Gale (1994) who concludes that companies need a strategic system to provide data on customer value performance. A conclusion that goes well in hand with the attention the industry gives to formal customer evaluations; however, when it comes to measuring customer satisfaction, there is no generally accepted standard of how to conduct this measurement (Gilbert and Veloutsou, 2006).

Several variants of how to measure customer satisfaction are currently in use (Eboli and Mazzulla, 2009). In current literature about customer satisfaction, the three most explored methods are the expectancy-disconfirmation paradigm, the perceived performance paradigm, and the view of cumulative satisfaction (Johnson et al., 2001). All three paradigms have their own strengths and weaknesses, but the main difference lies between the first two. The expectancy-disconfirmation paradigm takes the expectations of the customer into consideration, whereas the other two do not. Also, the cumulative satisfaction paradigm takes into consideration the prior experience of the customer, which serves as a cognitive anchor (Johnson et al., 2001). Even if all tests do not measure the customer's expectations and/or experience, it is recognized as an influence on the customer's perception of the quality of the service delivered.

As Grönroos (2008) also concludes, the quality of the service is always based on the customer's expectations and/or experience. Parasuraman et al. (1985) take it one step further, 
stating the quality evaluation is not solely based on the outcome of a service; the process of the service delivery is taken in account as well. At the same time, simply accommodating the tenant's specific needs can influence retention equity-needs which customers often find difficult to articulate (Pinder et al., 2003), making the evaluation of customer satisfaction difficult. This difficulty in taking everything into consideration when designing the evaluation and measuring customer satisfaction is one of the main arguments for the perceived performance evaluations (Johnson et al., 2001).

Current literature highlights the importance of measuring customer satisfaction in real estate management (see, for example, Baharum et al., 2009, Palm, 2008 and Chin and Poh, 1999). To remain competitive, real estate companies must listen and respond to their tenants' needs and expectations (Chin and Poh, 1999). A study of the use of formal evaluations in real estate management in Sweden (Palm, 2008) reveals that the evaluations seldom start with the tenants' needs a reflection shared with Baharum et al. (2009) who also conclude that property managers tend to focus only on variables which can easily be translated into cost reduction.

In general, the measurement of customer satisfaction is considered a post-consumption assessment by the user regarding the service provided (Gilbert and Veloutsou, 2006). However, in the real estate industry, the measurement is conducted during the ongoing service delivery with the tenants still contracted, making this situation quite unique. This helps the industry collect the best material because it is generally observed that the sooner the assessment is done to the actual service delivery, the more correct the assessment of the quality. However, Mittal et al. (1999) argue that the sooner the customer's evaluation is conducted relative to the time of service also means the most recent customer contact may influence the customer's overall rating. This implies a risk for bias if the customer has had a particularly good or bad service experience closer to the time of the evaluation.

\subsection{The Swedish Real Estate Barometer}

The Swedish Real Estate Barometer (SREB) is based upon a survey conducted with tenants to the participating real estate company. For every participating real estate company the survey is distributed to up to 100 tenants, randomly selected (i.e. all of the companies' tenants are never included). It was founded in 1995 as a subdivision of the Swedish Customer Satisfaction Barometer (SCSB). The SREB (and SCSB) takes as its foundation the perceived performance paradigm and does not measure/test for customer expectations.

The survey is distributed by post or electronically through the Internet. To secure the response rate, two reminders are distributed if necessary. The survey is conducted yearly, and the top three companies with the highest overall score are presented; however, companies with a lower score can also be presented if they so desire. All the companies get a report of results along with the possibility to have an analysis conducted. This benchmarks the company against the industry as a whole while, at the same time, enabling them to do internal revising.

\section{Research design and methodology}

This article is based on a study of twenty-four original companies' annual reports and an interview study with fifteen top-level managers from those twenty-four companies. The twenty-four companies were selected by using the same companies Palm (2011) used. This means being able to refer to Palm's categorisation of the companies as either customer, project, financial, or brick oriented. All of these companies are real estate companies, which own and manage commercial premises (no residential companies were included). First, the 
research for this article involved checking if these twenty-four companies participated in SREB and/or make formal customer evaluations. Second, an interview study was conducted with top-level managers from fifteen of the twenty-four companies. The aim of the interview study was to identify top management's motives for whether or not to measure customer satisfaction.

\subsection{Data collection}

The respondents interviewed are all top managers from fifteen real estate companies. As defined by Patton (2002) and Eisenhardts (1989), the selection is a stratified, purposeful sample made to include a wide range of commercial real estate firms representing companies who conduct formal evaluations, as well as companies that do not, with all falling into four categories (as defined in Palm, 2011): customer, project, financial and brick oriented. The selection is shown in Table I. The first figures refer to companies interviewed in every group and the figures in parentheses refer to the original twenty-four companies included in the annual report study:

Table I. Participating companies

$\begin{array}{lccc} & \text { Small } & \text { Large } & \text { Total } \\ \text { Customer } & 3(5) & 3(6) & 6(11) \\ \text { Project } & 4(4) & & 4(4) \\ \text { Financial } & 3(5) & 2(3) & 5(8) \\ \text { Bricks } & 1(1) & & 1(1) \\ \text { Total } & 11(15) & 4(9) & 15(24)\end{array}$

To be regarded as small, the company should have a-revenue between €50-999 million and to be categorized as large, the company should have a-revenue over $€ 1,000$ million. The reason for excluding companies with revenue under $€ 50$ million is because they usually do not have the same incentive and resources to work with formal customer evaluation. The selection of the four specific categories enables the discussion to be on a more general level concerning the commercial real estate industry in Sweden. The strategic selection is preferred given that this study does not seek to make any statistically evident conclusions regarding use of formal evaluation in the real estate industry.

The interview process followed the same structure; all were semi-structured based on Kvale's (1995) structure with the starting point in a more comprehensive question regarding measurement of customer satisfaction. The questions were influenced by Morgan et al.'s (2005) research "Understanding Firms Customer Satisfaction Information Usage” where they do qualitative in-depth interviews and the first phase of Caemmerer and Wilson's (2010) study "Customer Feedback Mechanisms and Organisational Learning in Service Operations". Every interview has its own unique setting because all of them concerned how the companies presents their work and include formal evaluations of customer satisfaction in their annual reports. The basic intention was to conduct the interviews as a conversation about their motives to measure customer satisfaction.

A key approach for mitigating bias in interview studies is to combine the interviews with retrospective material. In this study, all interviews are preceded by a study of each company's annual report; a working procedure that not only reduces the risk of bias, but also provides an understanding of both the company at hand and its view on customer relations.

\subsection{Data analysis}


The inventory regarding the use of formal customer evaluations made it possible to get an overview of the industry. If the annual report did not include the information regarding how the company used formal customer evaluations, contact with the company was made to ensure the information for the inventory is correct; however, this was only necessary in two cases where neither of the companies used formal evaluations.

To enable sorting, interpreting, classifying, and coding of the interview material, all interviews were recorded and all of the material transcribed. This working procedure enabling a better overview and understanding of the material while securing the process and ensuring that the respondents are correctly quoted. Taping and transcribing is also a working procedure that is considered essential when working with this type of interview material (see, for example, Riessman, 1993).

\section{Findings}

In this section, the result from the study will be presented. This section presents the basic inventory regarding the use of formal customer evaluations and participation in the SREB. Second, a presentation of the interview study conducted is made in order to better understand how the top managers reason about formal customer evaluations.

From the inventory, a classification of the Swedish real estate companies into three ideal types has been made, which is presented in Table II. The three ideal types; Participate in the SREB; Conduct formal valuations of their own; and Do not conduct any formal customer evaluations. In adition to this the categorisation of Palm (2011) of the companies as either being Customer, Project, Brick or Financial oriented is added together with the size of the companies.

Table II. Formal measuring of Customer satisfaction 


\begin{tabular}{|c|c|c|c|c|c|}
\hline Size & Categori & SREB & Own & None & Interview \\
\hline Small & Customer & $x$ & & & \\
\hline Small & Customer & & & $x$ & $x$ \\
\hline Small & Customer & & & $x$ & $x$ \\
\hline Small & Customer & & & $x$ & $x$ \\
\hline Small & Customer & & & $x$ & \\
\hline Small & Project & $x$ & $x$ & & $x$ \\
\hline Small & Project & & & $x$ & $x$ \\
\hline Small & Project & & & $x$ & $x$ \\
\hline Small & Project & & & $x$ & $x$ \\
\hline Small & Financial & $x$ & & & $x$ \\
\hline Small & Financial & $x$ & & & \\
\hline Small & Financial & & & $x$ & $x$ \\
\hline Small & Financial & & & $x$ & $x$ \\
\hline Small & Financial & & & $x$ & \\
\hline Small & Brick & $x$ & & & $x$ \\
\hline Large & Customer & $x$ & $x$ & & $x$ \\
\hline Large & Customer & $x$ & $x$ & & \\
\hline Large & Customer & $x$ & & & \\
\hline Large & Customer & & $x$ & & $x$ \\
\hline Large & Customer & & & $x$ & \\
\hline Large & Customer & & $x$ & & \\
\hline Large & Financial & $x$ & $x$ & & $x$ \\
\hline Large & Financial & $x$ & & & \\
\hline Large & Financial & & $x$ & & $x$ \\
\hline Total & & 10 & 7 & 11 & 15 \\
\hline Small $=15$ & \multicolumn{5}{|c|}{ Customer $=11$} \\
\hline Large $=9$ & \multicolumn{5}{|c|}{ Project $=4$} \\
\hline & \multicolumn{5}{|l|}{ Financial $=8$} \\
\hline & \multicolumn{5}{|l|}{ Bricks = 1} \\
\hline
\end{tabular}

From Table II, we can conclude that eleven out of twenty-four companies do not make any formal evaluation of customer satisfaction. However, this does not mean they do not work with customer relations, as five of these are regarded as customer-oriented in a previous study conducted by Palm (2011). Four of the remaining companies conduct formal evaluations themselves as well as participate in SREB.

In the next section, which is structured by the three classifications, the top managers' arguments for whether or not they conduct customer evaluations are outlined and analysed.

\subsection{Participating in SREB}

Sweden has a strong tradition when it comes to making indices and measuring customer satisfaction (Fornell, 1992). The following examples are found when analysing top managers' arguments regarding why one should participate in the national SCI:

We intend on participating in the SREB every second year, as some tenants perceive it as disturbing if we participate every year. A year goes by quickly, and 
there are many questions to answer in the questionnaire. Plus, you have to be able to take care of the result internally and make something good out of it. We participate because we want to check how we are perceived in relation to the rest of the industry. (We did not do it before 2008 and wanted to know how would be rated, and of course, to be able to gain some deeper knowledge. We measure on our own on a regional level and make an internal benchmark out of that as well to see what our customers are and are not satisfied with....) What can we change to make them more satisfied? Sometimes, even small details which can easily be changed make a big difference to the customer. This has resulted in us making some changes to our routines.

(Small project-oriented company)

This company participates in the SREB to get a heads-up regarding how they perform compared to their competitors. They also receive input regarding what the customers would like improved. However, this input and feedback seems mainly to be from their own evaluation. Therefore, the main reason for this company to do the evaluation seems to be to compare themselves with their competitors.

As one of the largest players, you should be a part of the SREB. Who else should? If your business idea is to own and manage real estate long term, then your customer relations are the key to success. In this case, you have to measure customer satisfaction. We conduct our own measurements to develop internally, and we also participate in SREB to be able to compare ourselves with the industry and not be outrun by our competitors. The SREB isn't distributed to all of our customers. Only a selection of our customers are chosen, and the questionnaire is not as detailed as our own. Our own questionnaire is distributed to everyone leasing more than fifty square meters and it contains questions that are more detailed and better suited for development.

(Large customer-oriented company)

The answer from this company is somewhat ambiguous. They clearly state that participating in the SREB is relevant and of the highest importance. However, they also state that not all of their customers get the SREB questionnaire, yet they do get the company's own questionnaire. It appears it is the company's own questionnaire and evaluation is used for developing the organisation and improving routines. What remains is simply comparing the business with the industry, thus demonstrating that having satisfied customers is important.

Another respondent highlighted the benefit of participating in the SREB by stating:

The main benefit is that you are forced to meet your customer and their companies. There is a questioner that have to be filled and taken care of and protocol to be filled.

(Small customer oriented company)

However, the companies participating in the SREB also gave it some critique. As one respondents stated:

The problem with SREB is the location contributes enormously and it is fairly easy to deliver the service required in good locations because at the same time the rents are very high. It is hard for us when we have a building more on the country 
$\underline{\text { side. Even if you measure a kind of index it is two entirely different products in a }}$ way.

(Large customer-oriented company)

Furthermore the critique of the SREB regards the cost of participation and that the result is not public not even for the participating companies.

You cannot compare yourself with the rest of Sweden. The main problem with it (SREB) is that it is voluntary to share the result. Only the best are presented and the rest are never displayed unless they do it themselves. What kind of ranking is that? In my opinion, it is ridiculous, and I can't take it seriously as long as they have this setup. And then it is relatively expensive to participate, very expensive. We are able to run our own evaluation much cheaper with more or less the same structure. I know they have some kind of twist in their regression analysis, but it doesn't add anything if you ask me, not compared to the amount of money it costs anyhow.

(Large customer-oriented company)

The company states that comparing a business with the rest of the industry cannot be done. However, the primary reason seems to be that they can make their own, more cost-effective evaluation. The main point of participating in SREB seems to be to compare with competitors and the industry as whole as well as signal to work with customers and having satisfied customers is important.

\title{
5.2 Conducting formal customer evaluation of themselves
}

One alternative to participating in the SREB yet still be able to make formal customer evaluations is for the company to conduct them themselves. The top managers' arguments for why business should conduct them themselves:

\begin{abstract}
We have our own [evaluation] where we compare yearly. We do this every second year and at every level, janitor versus janitor and so on. We benchmark within the company, so we don't use a common questionnaire. A couple of years ago, we tried to measure customer satisfaction and participated in the SREB in order to compare with other companies, but it cannot be done. There are so many complicated parameters involved. However, because we are able to benchmark within the company, I think we have a relatively good picture of our customers and what makes them satisfied or not. The conclusion from participated in the SREB was that it is easier to find satisfied customers in "bad houses" than in "good houses". In "good houses" where you have higher rents, you also have higher expectations on you from the customer's side. This implodes when you mix these and compare them with each other; then it easily becomes a case of those with worst houses get the best rates. That was our conclusion when participating in the SREB. That also made the score irrelevant. If you are to make these kind of indices, you have to know what kind of house it is and what type of customer occupy the house.

(Large financial-oriented company)
\end{abstract}

This company states that measuring and benchmarking are important for improving their business. Their reasons for doing this themselves and not through SREB is stated to be partly because the questionnaire distributed by SREB is not good enough, as it does not take all 
relevant parameters into account, and also because the index created by SREB does not take certain other parameters into consideration, for example, what kind of tenant they may have on the landlors. As a result, the index measured does not live up to its potential relevance. Another respondent also highlighted these arguments, stating:

We conduct our own measurements to develop internally, (...) Our own questionnaire is distributed to everyone leasing more than fifty square meters and it contains questions that are more detailed and better suited for development (in comparison with the SREB questioner)

(Large customer-oriented company)

The respondents highlighted the fact that the questioner must have a different design to support internal development. Furthermore it highlights the fact that the company at hand do prioritise the question of service to the extent that they perform both the SREB and a survey of their own. This is a viewpoint shared by the other companies that have developed their own customer survey.

\footnotetext{
You cannot compare yourself with the rest of Sweden. The main problem with it (SREB) is that it is voluntary to share the result. Only the best are presented and the rest are never displayed unless they do it themselves. What kind of ranking is that? In my opinion, it is ridiculous, and I can't take it seriously as long as they have this setup. And then it is relatively expensive to participate, very expensive. We are able to rum our own evaluation much cheaper with more or less the same structure. I know they have some kind of twist in their regression analysis, but it doesn't add anything if you ask me, not compared to the amount of money it costs anyhowWe have developed our own survey, or to be true we have had a consultant to do it. But we were involved in the making and we have successfully made it better and better every year enabling us to customize it to our own requirements and pinpointing focus areas that we in the board find as extra crucial to investigate.

(Large Customer-oriented company)
}

The respondent highlights that they have an in-depth interest in their customers and by being able to develop their own survey they have been able to pinpoint relevant areas. However, this also results in that they will not be able to measure the development over time as they are measuring different things every year.

The companiesy states that comparing a business with the rest of the industry cannot be done. However, the primary reason seems to be that they can make their own, more cost-effective evaluation.

Taking all seven of the interviews into account where the companies make formal evaluation of their own (of those seven, four also participate in SREB), we find that the reason for this is because they need more in-depth information to be able to improve their work and they cannot get it any other way. The SREB is not as detailed or does not contain all of the desired parameters.

\subsection{No formal customer evaluation are made}

Of the twenty-five companies, eleven do not conduct any formal evaluations of customer satisfaction. When analysing the top managers' arguments, the following examples are found: 
When you have only about a hundred customers as we do, you can meet them all. I think that many of our larger customers would take offence if we would expose them to a traditional SCI survey. When it comes to our larger customers, then it is the district manager and I as managing director who have customer contact, and it is at least monthly. I would say that with our most important customers, we have a dialogue every week. It is the model that we have chosen. In this case, you can't know if the customer thinks its great or not by a survey or other measurements. But on the other hand, after every meeting you will get a feeling for the atmosphere. How does it work for you here? But it is also because we are an important and a large supplier for the customer that they have the time to sit down with us.(...) I think that the customer often underestimates or can't imagine how a good customer dialogue with the real estate company can be done. It can be because their own business is static. You can imagine a regular office customer: its organization neither grows nor decreases, and in that case, it only has a dialogue every third year with the real estate company when the contract is up for negotiation. But we work following the companies, and you need to be prepared to take both the epsides and downides. To be able to do this, you need a constant dialogue with the customer.

(Small project-oriented company)

This citation states the reason for not working with formal evaluations is because they already have a constant dialogue with their customers. Furthermore critique regarding what you actually are measuring in a formal customer evaluation is brought up. One is that customers do not know what good service is and another is that there would not be an interest among their customers to answer a questionnaire.

We live with our customers. It is up to every unit to have a constructive dialogue with the customer. It is their customer, and it is their responsibility to follow up on them. We don't do any SCI or anything like that, because you do not need to. As I see it, you would only need to do that if you are distant from the customer. If you know your customer and see them daily, you don't need to send out any questionnaire or SCI questions. It should be incorporated in the daily routine and not just a matter of dealing with how things work today. It should also incorporate questions such as "what else can we do for you?" and we have that incorporated as a natural part of our working procedure.

(Large customer-oriented company)

The perspective of this company is that if a company works closely with its customers and develops an effective dialogue where it tries to catch all of the questions early on, then it does not need to conduct any formal evaluations. The person at hand even states that if a company has to conduct evaluations, then it is already too distant from its customers.

How a constant dialogue and/or close work with the customer would make formal evaluations obsolete is not clear. Nevertheless, a company may still get important input by conducting an evaluation. It would get any outstanding issues on the table and be able to work with questions on a more strategic level instead of on an individual manager level. In addition, customers may have questions that they would not be comfortable asking face to face, but are able to ventilate when filling out an evaluation form. 


\section{Discussion}

Conducting formal customer evaluations and participating in the SREB are ways of working and developing a company's service concept. Furthermore, it is a way to benchmark a company with other companies and within the organisation. Previous studies have shown that the real estate industry has developed to become more service and customer-oriented (Phillips and Roper, 2009). Also taking Sandersson (2015) conclusion, the tenants' wants to have a well functioning communication with the management, should be a crucial incentive to make customer evaluations. This also implies that measuring customer satisfaction should be of great interest for the industry. Sweden's strong tradition when it comes to measuring customer satisfaction is another factor contributing to the interest.

Table III. Gustomer evaluations dependent on categorizationCompanies participating in the SREB

\begin{tabular}{|c|c|c|c|c|}
\hline & \multicolumn{2}{|c|}{ Small } & Large & Total \\
\hline Customer & \multicolumn{2}{|c|}{$\underline{20 \%}$} & $33 \%$ & $45 \%$ \\
\hline Project & \multicolumn{2}{|c|}{$\underline{25 \%}$} & $=$ & $25 \%$ \\
\hline Financial & \multicolumn{2}{|c|}{$\underline{40 \%}$} & $\underline{67 \%}$ & $\underline{50 \%}$ \\
\hline Bricks & \multicolumn{2}{|c|}{$100 \%$} & & $\underline{100 \%}$ \\
\hline \multirow[t]{2}{*}{ Total } & \multicolumn{2}{|c|}{$33 \%$} & $\underline{67 \%}$ & $\underline{46 \%}$ \\
\hline & SREB & Own & None & Total \\
\hline Customer & 4 & 4 & 5 & 13 \\
\hline Project & 1 & 1 & 3 & 5 \\
\hline Financial & 4 & 2 & 3 & 9 \\
\hline Bricks & 1 & - & - & 1 \\
\hline Total & 10 & 7 & 11 & 28 \\
\hline
\end{tabular}

From table III we can see that only $46 \%$ (11 out of 24 ) of the companies do participate in the SREB. It is unusualunexpected that as many as five out of eleven customer-oriented companies and three out of five project-oriented companies do not conduct formal customer evaluations. The companies in Palm's (2011) study were considered to work with their customers in a more extensive way than the companies in the other two categories. We can also see that only 33\% (5 out of 15) of the small companies participate. It is notable that only one out of five companies that, by Palm (2011) definition, is costumer oriented participate in the SREB. This might be due to the high cost to participate that is stated by several of the respondents. However, if you truly is customer oriented then you aught to prioritise these kind of commitment. To bare in mind is that, even if categorised as small, none of the companies have a revenue below $€ 50$ millions, so even if it is costly there should be possibilities to prioritise if there is a real willingness among the company executives. Could it instead be that Palm (2011) is wrong in his classification, or has something happened in the time between Palms study and this study? After all, more than five years has passed between the Palm 2011) study, the material in that study is from the time period of 2004-2008. It can be that company executives has been replaced or it is as simple as the annual reports being an advertising product not anchored in the actual every day work and the company executives agenda?

Either way it is remarkable that only $46 \%$ of the commercial real estate companies are participating in the SREB. This also limits the use of the SREB as it is market as and stated by the company executives to be used for benchmarking purpose. If not even half of the companies participate then the use in benchmarking purpose are strictly limited as you do not 
know it companies performing well do participate or not. This is also complicated by the SREB not stating which companies that participate and only publish the three companies with best overall scores.

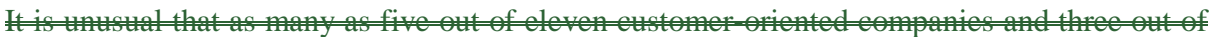
five project-oriented companies do not conduct formal customer evaluations. The companies in Palm's (2011) stly ons a than the companies in the other two categories.; howeverHowever, those who have a customer focus in the organisation might have other customer routines in their daily working procedure which make the SREB and other formal evaluations-superfluous within the organisation. For example the interviews concluded that the SREB might not be the best tool to drive change and develop the organisational service approach. Instead the performance of in-house evaluations or the development of formal customer evaluations of their own was stated to be better.

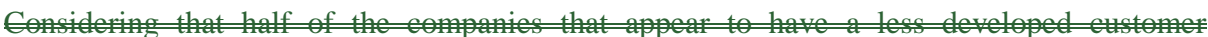
orientation relationship (the financial and brick oriented companies) are seen to paticipate in the SRIB could indieate that they see the SREB as a "loophole". If participating, they ean

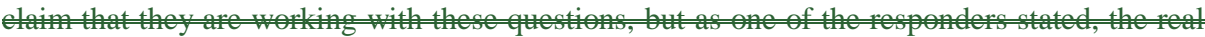
work begins afterwards. The organisation must take the feedback into consideration and de

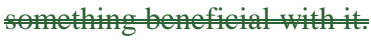

\begin{tabular}{|c|c|c|c|c|}
\hline & \multicolumn{2}{|c|}{ Small } & Large & Total \\
\hline Customer & \multicolumn{2}{|c|}{$0 \%$} & $67 \%$ & $36 \%$ \\
\hline Project & \multicolumn{2}{|c|}{$25 \%$} & - & $25 \%$ \\
\hline Financial & \multicolumn{2}{|c|}{$\underline{0 \%}$} & $67 \%$ & $\underline{25 \%}$ \\
\hline Bricks & \multicolumn{2}{|c|}{$\underline{0 \%}$} & z & $0 \%$ \\
\hline Total & \multicolumn{2}{|c|}{$7 \%$} & $67 \%$ & $29 \%$ \\
\hline & SREB & Own & $\overline{\text { None }}$ & $\overline{\text { Total }}$ \\
\hline Small & 5 & 1 & 9 & 15 \\
\hline Large & 5 & 6 & 2 & 13 \\
\hline Total & 10 & 7 & 11 & 28 \\
\hline
\end{tabular}

From Table IV, we can see that the larger companies dominate the in-house constructedformal customer evaluations. If we were interested in studying larger companies, then we most certainly would have seen more companies participating in the SREB and empanies that conduct formal evaluations of their own. However, as of 2015, no additional larger commercial real estate companies exist in Sweden.

In Table IV we can see that only $36 \%$ of the customer and $25 \%$ of the project oriented companies do perform evaluations of their own.

One explanation for why larger companies make their own evaluations more often could be that they are administratively heavy to conduct, even if you use a consultant. On the other hand, participating in the SREB might not be as administratively time-consuming. As some respondents stated, the SREB does not give the same in-depth feedback; when a company conducts the evaluation itself, it can delve into questions in depth. However, this also generates more feedback, which needs to be taken care of and implemented within the organisation. 
Regardless of participating in the SREB or conducting evaluations of their own we can conclude that all large companies exept one conduct formal evaluations. The notable is that the large company not conducting a formal customer evaluation is by Palm (2011) categorised as customer oriented. This does not go hand in hand. It is a company that has both the economical and organisational ability to perform formal customer evaluations. The only possibility is that the company either has changed focus or that it was wrongly categorised.

\section{Conclusion}

Considering that half of the companies that appear to have a less developed customer orientation relationship (the financial and brick-oriented companies) are seen to participate in the SREB could indicate that they see the SREB as a "loophole". If participating, they can claim that they are working with these questions, but as one of the responders stated, the real work begins afterwards. The organisation must take the feedback into consideration and do something beneficial with it.

The SREB appears to be a good instrument for getting a "feel" for a company's ranking amongst its competitors. However, to use the results for real change and improvement, the respondents prefer to do the evaluations themselves. One suggestion is for SREB to compose a "light" version of the index, thus enabling everyone (for a lesser fee) to participate and also get a better idea of where they stand. It may even be more relevant because more companies would participate and for the companies that want to use the evaluation for improvement and development, a more extensive evaluation could then be offered. This way, the companies could participate in the index every year and perhaps every second or third year choose to conduct customer evaluations for the improvement and development of their customer relations.

The strategies for conducting formal customer evaluations can be divided in two main strategies. The first strategy is to see, and possibly use, formal customer evaluations in the continuously improvement process. The second strategy is to see the participation in SREB as a signalling of service orientation and thereby quality.

First, if we regard strategy one and consider the critique of the SREB, it is clear that the company has to make a complementary, or completely freestanding, evaluation ot their own. This is mainly due to the critique stating that the questions is not as in-depth as they aught to be and that you can not compare different properties in different locations and with different customers with different needs and expectations with each others. It can only be used as a heads up regarding how you generally perform and your progress since last year. But to really be able to compare with the industry you be able to compare with companies you know have a similar structure as your self. But, as previously stated, only the top three companies are displayed with their names. These three all might be in a completely different segment of the real esate industry than your self.

Second if we regard strategy two, there are components if we take the critique towards SREB together with Palm (2011) classification in regard a tendency to use the SREB as a signalling of quality. Because, if you are able to show the market that you do customer evaluations on a regularly basis then the market will consider you as a company that are customer oriented and maybe thereby more positive to lease from that company. Since there seem to be a consensus 
in the critique that you cannot use the SREB alone to identify what kind of improvement work that has to be initiated then the participating in SREB is only in marketing purpose.

To sum up it is clear that you can use your annual report to signal customer orientation, but how you truly work with your customer and service processes is another question. The same goes for the company's participation in the SREB. It can either provide an insight for the company regarding the provided service and the customer work but it might as well only be used as a signalling system towards the market signalling that you are a customer focused company. The question is does the market buy it?

\section{Implication for further research}

All companies participating in the SREB highlights this in their annual reports and other advertising material. However, I can not see that they in other ways are working customer focused. Therefor, it would be interesting to see it the market consider the participation in SREB as a quality signal.

Because not all customer-oriented companies conduct formal evaluations, one must ask how they work with their customers instead. What alternatives are there when it comes to customer follow up, and how do they develop-eustomer strategies based on their eustomers' needs and preferences?

Also it would be interesting to make a variant of the study by combining Westlund et al. (2005) including the financial performance of the company and Sanderssons (2015) determinants of satisfaction to see how the companies work with, customer evaluations and the identified espoused values (Palm, 2011) of the commercial real estate companies. It would be intriguing to be able to assess the value of having a clear service and customer focus in relation to companies only signalling customer orientation and companies without signalling and no customer focus. Is it profitable for commercial real estate companies to have a customer focus or not? 
References

Aksoy, L., Cooil, B., Groening., Keinigham, T. L., and Yalcin, A. (2008), The long term stock market valuation of customer satisfaction, Journal of marketing. Vol. 72, pp. 105-122. Appel-Meulenbroek, R. (2008), Managing “keep” factors of office tenants to raise satisfaction and loyalty, Property Management, Vol. 26 No. 1, pp. 43-55.

Baharum, Z. A., Nawawi, A. H., and Saat Z. M. (2009), Assessment of Property Management Service Quality of Purpose Built Office Buildings, International Business Research, Vol. 2 No. 1, pp. 162-174.

Carmmerer, B. and Wilson, A. (2010), Customer feedback mechanisms and organisational learning in service operations, International journal of operations \& production management, Vol. 30 No. 3, pp. 288-311.

Chin, L., and Poh L. K. (1999), Implementing quality in property management -The case of Singapore, Property Management, Vol. 17 No. 4, pp. 310-316.

Dogge, P. and Smeets, J. (2004), In search of customer loyalty - a research into the relationship between tenants satisfaction and commitment, Revista de psihologic Aplicata, special issue 18th IAPS-Conference, Vol. 6 No. 3-4, pp. 111-120.

Eboli, L. and Mazzulla, G. (2009), A New Customer Satisfaction Index for Evaluating Transit Service Quality, Journal of Public Transportation, vol. 12, No. 3, pp. 21-37.

Eisenhardts, K. (1989), Building theories form case study research, Academy of Management Review, vol. 14, No. 4, pp. 532-550.

Fornell, C. (1992), A National Customer Satisfaction Barometer: The Swedish Experience, The Journal of Marketing, Vol. 56 No. 1, pp. 6-21.

Gale, B. T. (1994), Managing customer value: creating quality and service that customers can see, New York, The free press.

Gallarza, M.G., Gil-Saura, I., and Holbrook, M.B. (2011), The value of value: Further excursions on the meaning and role of customer value, Journal of Consumer Behaviour, Vol. 10, No. 4, pp. 179-191.

Gee, R., Coates, G. and Nicholson, M. (2008), Understanding and profitability managing customer loyalty, Marketing Intelligence and Planning, Vol. 26, No. 4, pp. 359-374

Gilbert, R.G. and Veloutsou, C. (2006), A cross industry comparison of customer satisfaction, Journal of service marketing, Vol. 20 No. 5, pp. 298-308.

Grönroos, C. (2008) Service Management och marknadsföring Liber Sverige.

Johnson, M. D., Gustafsson, A., Andreassen, T. W., Lervik, L. and Cha, J. (2001), The evolution and future of national customer satisfaction index models, Journal of Economic Psychology, Vol. 22, pp. 217-245.

Jones, T. O. and Sasser Jr., W. E. (1995), Why satisfied customers defect Harvard Business Review, nov-dec, 1995.

Kristensen, K. and Westlund A. H. (2004), Performance measurement and business results, Total Quality management, Vol. 15, pp. 729-743.

Kvale, S.. (1995) Den kvalitative forskningsintervjun. Studentlitteratur, Lund

Kärnä, S. (2004), Analysing customer satisfaction and quality in construction -the case of public and private customers, Nordic Journal of Surveying and Real Estate Research, Special Series, Vol. 2, pp. 67-80.

Kärnä, S., Sorvala, V.-M. and Junnonen, J-M. (2009), Classifying and clustering construction projects by customer satisfaction Facilities, Vol. 27 No. 9/10, pp. 387-398.

Lai K. C., Hui, Y. V., Lo, H. P., Tse, S. K., Tso, G. K. F. and Wu, M. L. (2003), Consumer satisfaction index: new practice and findings. European Journal of Marketing, Vol. 37 No 5/6, pp. 872-909. 
Li, M. (2003), Quality loss functions for the measurement of service quality, International journal of advanced manufacturing technology, Vol. 21, pp. 29-37.

Lind, H \& Lundström, S. (2011), Kommersiella fastigheter i samhällsbyggandet, SNS Förlag, Stockholm.

Lindholm, A.-L. (2008), A constructive study on creating core business relevant CREM strategy and performance measures, Facilities, Vol. 26 No. 7/8, pp. 343-358.

Matzler, K. and Hinterhuber, H.H. (1998), How to make product development projects more successful by integrating Kano's model of customer satisfaction into quality function deployment, Technovation, Vol. 18 No. 1, pp. 25-38.

Mittal, V., Kumar, P. and Tsiros, M. (1999), Attribute-level Performance, Satisfaction, and Behavioral Intentions over Time: A Consumption-System Approach. Journal of Marketing. Vol. 63 No. 2. Pp. 88-101.

Morgan N. A., Anderson, E. W. and Mittal, V. (2005), Understanding firms' Customer satisfaction information usage. Journal of marketing, Vol. 69 No. 3, pp. 131-151. Palm, P. (2008), Closing the loop the use of Post Occupancy Evaluations in real estate management, KTH. Stockholm.

Palm, P. (2011), Customer orientation in real-estate companies: the espoused values of customer relations. Property Management. Vol. 29 No. 2, pp. 130-145.

Palm, P. (2013), Strategies in real estate management: two strategic pathways, Property Management, Vol. 31, No. 4, pp. 311-325

Parasuramani A., Zeirthaml, A. V., and Berry L. L., (1985) A conceptual model of service quality and its implications for future research. Journal of Marketing, Fall 1985.

Patton, M. Q. (2002), Qualitative research \& Evaluation methods 3ed. Sage Thousand Oaks Payne, A. and Clark, M. (1995) Marketing services to external markets, in Glynn, W. and Barnes, J. Eds. Understanding services Management: Integrating Marketing, Organisational Behaviour, Operations and Human Resource Management. Wiley. New York.

Phillips, D. R. and Roper, K. O. (2009), A framework for talent management in real estate. Journal of Corporate Real Estae,. Vol. 11 No. 1, Pp. 7-16.

Pinder, J. Price, L. Wilkinson, S.J. and Demack, S. (2003), A method for evaluation workplace utility. Property management, Vol. 21 No. 4, pp. 218-229.

Reichheld, F. F. (1996), The Loyalty Effect; the hidden force behind growth, profits and lasting value, Harward business school press, Boston MA.

Riessman, C. K. (1993), Narrative analysis. Qualitative research methods series 30 SAGE University paper.

Sandblad, J. (2007), Rätt lokal med rätt krav. Arbetsmodell för utvädering av lokalprojekt. Sandersson, D., C. (2015), Determinants of Satisfaction Amongst Occupiers of Commercial Property. In Arslanli K., Y. Book of proceedings, European real estate society $22^{\text {nd }}$ annual conference 24-27 June 2015 Istanbul, pp. 149-170.

Sanderson, D., C. (2014) Treating the Tenant as a Customer: can good service improve real estate performance?, Working Papers in Real Estate \& Planning 04/14, Henley Business School, University of Reading.

Storback, K., Strandvik, T., and Grönroos, C. (1994), Managing customer relationships for profit: The dynamics of relationship quality. Journal of service Management Vol. 5 No. 5 , pp. 21-38.

Tuli, K. R. and Bharadwaj, S. G. (2009), Customer satisfaction and stock returns risk. Journal of marketing. Vol. 73, pp. 184-197.

Westlund, A. H., Gustafsson, C., Lang, E. and Mattsson, B. (2005), On cuatomer satisfaction and financial results in the Swedish Real estate market. Total Quality Management, Vol. 16 No. 10, pp. 1149-1159. 
Zineldin, M. (2006), Quality and customer relationship management (CRM) as competitive strategy in the Swedish banking industry, The TQM Magazine, Vol. 17 No. 4, pp. 329-344. 